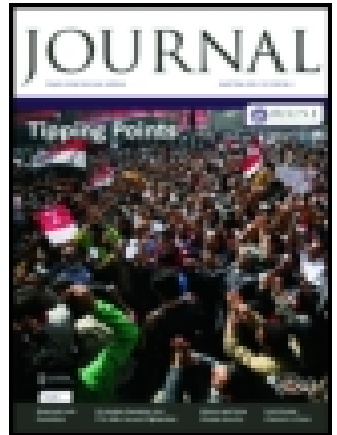

Royal United Services Institution. Journal

\title{
Training and Action Necessary to further Co- Operation between Artillery and Infantry
}

\author{
Major C. E. D. Budworth M.V.O.
}

To cite this article: Major C. E. D. Budworth M.V.O. (1913) Training and Action Necessary to further Co-Operation between Artillery and Infantry, Royal United Services Institution. Journal, 57:419, 67-86, DOI: $10.1080 / 03071841309420056$

To link to this article: http://dx.doi.org/10.1080/03071841309420056

册 Published online: 11 Sep 2009.

Submit your article to this journal $₫$

Џll Article views: 9

Q View related articles ¿ 


\title{
TRAINING AND ACTION NECESSARY
}

TO FURTHER CO-OPERATION BETWEEN

\author{
ARTILLERY AND INFANTRY. \\ By Major C. E, D. Budworth, M.v.o., \\ Royal Horse Artillery.
}

On Wednesday, 27 th November, 1912.

Lieut.-General Sir J. M. Grierson, k.c.B., c.v.o., c.M.G., in the Chair.

\section{MUTUAL KNOWLEDGE OF EACH OTHER'S REQUIREMENTS.}

ON the truth of the statement that infantry and artillery when acting in combination are more powerful than when acting independently it is scarcely necessary to insist. The acceptance of this statement at once gives us the key to the two great guiding principles of co-operation.

Combined action demands a central guiding brain-a single commander. It follows that this commander and his staft must possess a knowledge of the possibilities and limitations of both arms.

Command in the field must perforce be delegated, and consequently subordinate commanders and their staffs must also possess this knowledge. Since we have to deal with forces both large and small, junior officers may find themselves called upon to issue orders for the handling of a mixed force, and therefore they too require this knowledge.

Nor is it only a position of command which makes it requisite.

In the field there is little time for discussion and explanation.

This knowledge is essential in order that all ranks may carry out their orders with intelligence, and may exercise due initiative.

The first guiding principle of co-operation is, therefore, that all arms should be trained in a mutual knowledge of each other's requirements.

\section{CO.OPERATION MUST BE PRACTISED IN TIME OF PEACE.}

The required knowledge is not to be derived from books alone, and even if it could be so derived, it would not ensure the smooth working together of the arms in war. A more practical experience is requisite. The teachings of war prove co-opera- 
tion to be a product of peace training, and not one called into existence by a declaration of hostilities. We therefore obtain our second great guiding principle of co-operation. In order to ensure co-operation in war, it is essential to practise it in peace.

\section{WHAT IS BEING DONE AS REGARDS I. AND II.}

Is enough being done with regard to these two guiding principles?

To answer "No," is easy. But to-day I would rather insist on what is being done; satisfied that, although a few years hence our present standard may be regarded as defective, perfection in these matters must be the outcome of years of systematic and progressive peace training, and cannot be called into existence by a stroke of the pen.

Every effort is now made to render our training systematic. These efforts meet with a measure of success, severely hampered as they are by difficulties inherent in our system of recruiting and in supplying drafts for service abroad.

There are regimental, brigade, divisional and staff exercises and conferences; individual, regimental, brigade, and divisional training, all culminating in the annual Grand Manceuvres.

The policy of attaching officers to arms, other than their own, for instructional purposes may still be in its youth, but it is carried out to a much greater extent than heretofore.

Generally speaking, the broader the training officers receive, the better. The same holds good of the training of artillery units.

That artillery technical training can be carried too far, at the expense of a broad training, is a lesson of war. Those who follow our Instructions for Artillery Practice know that in recent years two important changes in policy have been introduced.

Firstly, the Divisional General no longer visits a practice camp as a mere onlooker, but to supervise and guide the training of his artillery. It is possible that in peace time the training of artillery could be carried out by artillery officers only, without any conspicuous ill-effects._ Officers of the other arms will have much to say, however, to the handling of artillery in time of war. The more experience they gain in time of peace, the better for themselves and the better for us.

Secondly, our authorities have recently seen fit to inaugurate certain changes in our system of practice, which, whilst safeguarding a thorough instruction in elementary practice, legislate for instruction in the tactical application of fire.

It has long been recognized that the first great lesson which artillery has to learn is to be able to hit, and that, 
unless it is able to hit, it is useless. It is now realized that not only must artillery be able to hit, but that it must be capable of applying that power of hitting to the best advantage of the other arms, and that this requires legislating for at our practice camps as well as elsewhere. Time must elapse before we can hope to derive full value from these instructions, the ultimate outcome of which will be an improved lnowledge of the principles and practical steps requisite for effective cooperation in the field.

Officers of the other arms attend our practice camps more regularly than formerly, and no doubt in the course of time we shall see arrangements for their instruction perfected, and more use made of their services when present. The presence of infantry and cavalry officers on the practice ground, and a free interchange of ideas, must serve to intensify the feeling of co-operation, and to inculcate a general knowledge of each other's requirements.

\section{IT IS NECESSARY TO FOSTER A BOLD ARTILLERY FIGHTING POLICY.}

The history of the wars of the last 50 years proves that the lack of a bold artillery fighting policy is fatal to co-operation. It proves, moreover, that such a policy is not to be called into existence by the roar of cannon and rattle of firearms, but must be fostered in time of peace.

Co-operation cannot be looked for, where guns are constantly brought on to the battlefield too late to be of material assistance; where guns are constantly held in reserve against eventualities, which may never occur; and where guns are never pushed forward in close support of infantry.

Artillery with its vast train of ammunition wagons, blocking the roads, and defenceless while on the move, must be a constant source of anxiety to a commander and his staff. The temptation to relegate it further to the rear is very great.

Great also on the battlefield is the temptation to hold it back to meet eventualities.

Our Artillery Instructions, in dealing with the principle of "Economy of Force," expressly warn us that this principle must always be subordinate to the necessity of employing sufficient force to attain the object in view.

Great battles, cannot, we know, be won without incurring losses. Nor can artillery, however high its technique, hope to carry out its task of co-operating efficiently with its infantry without running risks.

WVith the general policy of concealment as advocated in our Field Artillery Training I agree, except that personally I prefer the terms "partially concealed" and "concealed posi- 
tions " to "semi-covered" and "covered positions." But we must carefully guard ourselves against gauging a position by the immunity from loss that it confers, rather than by the extent to which it lends itself to the required task. Otherwise we may gradually come to think that a position in which losses are incurred is-de facto-a bad position.

Nor with regard to the close support of infantry, need we spend too much time discussing whether this support cannot be as well rendered from a distance, as from close at hand. It may or may not be; but neither you nor I can definitely say without a knowledge of the particular tactical and topographical circumstances.

We can afford to be bold in our peace training, linowing well that shot and shell quickly impose the necessary caution, while on the other hand, if we are over-cautious in peace the necessary disregard of risks is not likely to exist in war.

I trust that we artillerymen are duly imbued with the idea that no hill is too high to climb and no risk too great to be incurred in the support of our infantry. In any case, one could not afford to disregard the subject here, as war has too often proved how mighty is the spirit of self-sacrifice as a lever to co-operation.

\section{SUPERIOR EQUIPMENT OF ITSELF CONFERS GREAT ADVANTAGES.}

The experience of war proves that although an artillery, armed with a relatively inferior equipment may, thanks to its relatively superior training and spirit, co-operate more effectively with its infantry, than does the enemy's artillery, yet a superior equipment of itself confers great advantages.

In equipment, so far as I know, at the present day we can hold our own. It remains for us to weigh carefully what changes in equipment will be called into existence by the great developments which we see around us in motor traction, aeroplanes, electricity, etc.

\section{CO=OPERATION ON THE BATTLEFIELD.}

Given a mutual knowledge of each other's requirements, artillery and infantry trained conjointly and not in water-tight compartments, given also the right spirit and good weapons, what steps can be taken to ensure, as far as possible, effective co-operation on the battlefield?

Our divisional artillery consists of guns, howitzers, and heavy artillery. In order to combine and utilize their fire to the best advantage throughout an action, and to guide it constantly towards the desired goal, we must of necessity have: 


\section{A clear initial Plan of Action and Control by Superior Authority.}

If the control of the artillery is allowed in undue measure to devolve on subordinate commanders, the G.O.C. soon finds himself in the position of supervising the action of mixed forces of artillery and infantry rather than of commanding the two arms, artillery and infantry. He is thus deprived of the power of concentrating an overwhelming artillery fire upon the right place at the right time, a power which, ably applied, has so often proved the secret of success in battle.

In the many vicissitudes of an attack or a defence, where many troops are engaged, first one portion of the line may require support and then another. Nothing is easier than for the G.O.C. to direct his C.R.A. to carry out this support, provided he has batteries which have retained their mobility. If such guns are placed under the orders of subordinate commanders, they are likely to be drawn into the close support of infantry, and sacrifice their mobility, without reference to the general plan of action. With the loss of mobility guns cease to be available for general purposes. I conclude, therefore, that a G.O.C. will be cautious in allowing the command of his artillery to devolve on subordinate commanders, and that there is a grave risk that artillery, which has once been allowed to quit the fold, will not again be available for general purposes.

That guns should at times be placed under the command of subordinate commanders is unquestionable. The extent to which central control can be effectively exercised is largely dependent on topographical conditions rapidly descending in the scale as difficulties connected with field of view and communication increase.

The executive direction of the fire demands the undivided attention of one officer, and this naturally falls to the senior artillery officer.

It is necessary that the Artillery Commander should be in the confidence of the General Oficer Commanding.

This should be, and I believe is, ensured both by our organization and training.

\section{Preliminary Reconnaissance on the part of the Artillery Commander is essential.}

It is not only a question of being able to locate as far as possible the enemy's dispositions, but it is also a question of drawing up a well thought out plan, in which field guns, howitzers, and heavy artillery may best be enabled to play their respective rôles. Observation over the field of 
fire may be systematically organized; communication may be established with a view to the rapid collection and dissemination of information, and, in short, everything may be done towards a scientific combination of fire, which may be rapidly directed in accordance with the needs of the moment.

The initial positions occupied by the artillery often form the frame-work of the battle.

If these positions are occupied without reference to the general plan of action, faulty dispositions will result which will later be difficult to rectify.

The reconnaissance must be continued during action, and supplemented by that of subordinate artillery commanders.

The Artillery Commander must remain in close touch with the General

Officer Commanding throughout the Action and in sure and rapid

Communication with his Subordinate commanders.

This is necessary in order that he may retain a grasp over the situation as a whole, promptly direct the co-operation of the artillery placed at his disposal according to the orders of the G.O.C. or vicissitudes of the fight, and assist his subordinate commanders by furnishing them with information, which they might otherwise find it difficult to obtain.

As the fight progresses, new batteries may have to be placed under the orders of subordinate commanders of the other arms, or possibly batteries already so allotted may have to be withdrawn for general purposes. Such matters present difficult problems, the solution of which is likely, at any rate, to be facilitated by the general principles above mentioned.

I take this opportunity of calling attention to the wisdom of two details of our artillery peace training :

Firslly:-The standard of training demanded from the personnel in communication work, a standard permitting not only the requirements of small artillery units to be satisfactorily performed in action, but rendering the personnel of general utility to the Service in war.

Secondly:-The energy devoted to the training of a large and efficient battery staff in the certain knowledge that the battery must be the nursery for the training of those N.C.o.'s and men, who will be required to perform skilled work on the staffs of higher artillery commanders, if not of battery commanders, in time of war.

\section{Control by Subordinate Commanders.}

Our Field Artillery Training tells us that "Units of the two arms associated for a distinct tactical operation should, as a rule, be under one commander." 
To further co-operation the same general principles enumerated above hold good for the guidance of the artillery by subordinate commanders, but their execution is somewhat modified by circumstances.

The Subordinate-Artillery Commander must be thoroughly conversant with the Plan of Action.

In order to ensure this he should personally, if possible, get into touch with the commander of the troops concerned. This commander is responsible for the plan of action, which includes that of the artillery placed under his orders.

It is most important that the artillery and infantry should be in possession of identical orders.

It would seldom suffice merely to order artillery to support an attack.

To what extent reconnaissance and consultation between commander and C.R.A. should be carried, it is difficult to say, and in any case it is inadvisable to attempt to lay it down definitely.

Have these officers been accustomed to working together? To what extent is the direction of the infantry advance determined by superior authority, or by the positions of neighbouring troops? Of what importance is the element of time? What is the personal equation of the commander concerned?

I think that the most which can be safely said is that the C.R.A. should accompany the commander, if reconnaissance takes place, and should be afforded an opportunity of giving counsel on the requisite action of the artillery.

Once the plan of action is settled, it behoves the artillery commander to be constantly looking ahead and doing all in his power to prepare for eventualities. Some artillery officers on these occasions make a free use of their officers and patrols on definite reconnaissance work. I believe this to be an essentially sound policy. Energy and initiative in this respect may be rewarded by success, much greater than can be foreseen at the time.

Possibly it may be difficult to find a satisfactory gun position, or what is even more important, a good observing station. Special steps may be required to obtain them, necessitating, perhaps, loss of life, in the conviction that losses thus incurred may ultimately result in economy of life.

\section{Communication must be maintained between the Subordinate} Commander and his C.R.A.

This is necessary, both because the plan of action is likely to undergo modification and because of the difficulties experi- 
enced by artillery in the conditions of modern war directing their fire to the best advantage of the other arms.

It is distinctly preferable that the C.R.A. should himself remain in immediate touch with his commander. One cannot afford, however, to be dogmatical on this subject. The position of the commander is not dependent on that of the artillery, and may possibly require to be changed somewhat frequently. Frequent changes of position are out of the question for the C.R.A., due regard being paid to the exercise of his command. When personal touch can for any reason no longer be maintained, an artillery officer should still accompany the commander. This artillery officer should be accompanied by such N.C.o.'s and men as are required to maintain the communication between the commander and C.R.A. This artillery officer, aided by his accompanying N.c.o.'s and men would report on the movements of friendly and hostile troops, and on all other matters tending to render the artillery fire most effective.

Aithough the artillery thus assists itself, it looks to the infantry also to furnish information. Such information, emanating perhaps from the firing line, would presumably be sent to the commander, be sifted by his staff, and forwarded to the C.R.A. through the above-mentioned channel.

The Subordinate Artillery Commander should be able to communicate rapidly with the fre units under his Command and with the Senlor Artillery Commander.

This principle requires no further elaboration.

\section{Artillery acting in support of Infantry when the control has not derolved upon the Subordinate Commander.}

Hitherto I have considered the artillery commander, who has been allotted a task necessitating co-operation with a certain force of infantry, as placed under the orders of the commander of that infantry.

Our Artillery Insiructions distinctly lay it down that whether this is the case or not, the artillery commander must open communication with the infantry commander, reporting to him in person, if possible, in order to obtain full information as to the character of the operation that he is to support, and the instructions as to the proposed method of its execution.

It is obvious that the commander of-let us say-an artillery brigade may be allotted a double task, such as watching a zone and supporting an infantry attack. His batteries may be on a flank of the zone of the infantry advance. It would not be difficult to imagine other problems more interesting or more complicated. It would be a hopeless task to attempt to deal with them in detail. 
I am not prepared to say that observance of the above principles will ensure the solution of such problems, but it will always tend to facilitate it.

There is one grave danger which has to be carefully guarded against, namely, confusion as to whose orders the artillery is working under. Even officers of my limited experience know how liable this is to occur, and how baneful are its results. I have seen it occur in war, and $I$ have seen it occur in peace.

If guns are allotted to a certain task, it is essential that explicit instructions be issued on this point. Failing this, both the officer commanding the attacking troops and the officer commanding the supporting guns are liable to be placed in a very awkward position.

Similar care is essential, when it is required, for any reason, to withdraw the support of batteries. placed under the orders of subordinate commanders, or allotted to some given task.

Whether control remain in the hands of superior or subordinate authority, in order, so far as possible, to ensure cooperation, we therefore require :-

I. Knowledge of the plan of action.

2. Communication maintained between the commander and his C.R.A.

3. Communication maintained between C.R.A. and his command.

I can claim no novelty for these principles. They are all legislated for in our instructions. If they appear unduly simple to achieve so great a result, I would ask you to watch the difficulties in endeavouring to co-operate incurred by artillery and infantry when they had but little previous combined training. Ask yourselves-what are the immediate causes preventing co-operation? What practical steps could be suggested in order to overcome these difficulties? Then finally consider what care in organization, equipment and methods of training are required to achieve perfection in these details.

\section{ARTILLERY DIFFICULTIES IN CO.OPERATION IN MODERN WAR.}

I alluded to the difficulties experienced by artillery under the conditions of modern war in directing its fire to the best advantage of the other arms.

I propose now to refer briefly to this subject. These difficulties may be summarized as:-difficulties in-locating the enemy's position-distinguishing between friend and foe-control and direction of fire-ammunition supply-movement on the battlefield. 
Unless the position of the enemy can be accurately located, and unless he is forced, in some measure, to expose himself, the results of artillery fire are likely to be very disappointing. ${ }^{1}$

Reconnaissance by telescope or field glass may fail to disclose the position. The real position may be covered by advanced posts, which the mounted troops have been unable to drive in. The enemy may decline in any way to divulge his strength or intentions until compelled to do so.

Efficient cover against artillery fire in the field is comparatively easy to obtain.

It does not much matter what the particular form of cover is. If oblique fire can be brought to bear-good. But, if not, field guns cannot destroy it, and the defenders may lie quite secure until such time as they are forced to expose themselves. Once they are exposed, your field guns can perform their task effectively.

It is true that howitzers may prove effective against troops behind cover, but it is even more important in their case than in that of field guns that the target should be accurately located.

It is to the action of the infantry that we artillerymen look to force the enemy into activity. We are thereby enabled to locate the hostile position, and are at the same time provided with a vulnerable target. It is for us, by covering fire, to protect the infantry from undue losses, whilst thus forcing the enemy into activity.

Hence, as we all know, the infantry advance and artillery action, or duel, to be successful, must form but one, and not separate, phases of the battle.

As the infantry, making every use of cover, advance, leaving their guns further and further behind, it becomes more and more difficult for the artilleryman to distinguish with certainty the movements of friendly from those of hostile troops. Mistakes one way or the other may prove equally disastrous. We are obliged to employ special men to assist us in this, and it is doubtful if this alone suffices.

So long as the troops opposing you are exposed to the accurate fire of your supporting guns, your losses are likely to be small. Remove or cease that artillery support and your losses become heavy. Artillery support is, therefore, well worth maintaining as long as possible.

So far as the risks you incur from your own guns are concerned, it is of little moment whether these guns are behind cover or in the open. It is of great moment, however, that the officer directing the artillery fire should be able to distinguish between friend and foe, should have a clear view of the target, and should retain the control of the fire in the hollow of his hand. 
Hence, as the fight progresses, artillery must close in under the covering fire of other guns. If this cannot be done by day, artillery must close in by night.

The fact that you are closing in pre-supposes, in my opinion, that your guns are gaining an ascendancy over those of the enemy. If this is not so, then in all probability your advance will, at any rate, be temporarily checked. This his to be borne in mind in considering concerted action on the part of troops thrown for any reason on the defensive.

Here, I think, in the later stages for artillery support, you have to rely to a much greater extent on initial dispositions.

To rely solely on the occupation of direct fire positions at this stage of the action is certainly hazardous, though as our Field Artillery Training enjoins, artillery must, should circumstances demand it, undertake the task without hesitation.

In the early stages of an action, artillery fire is not likely to prove capable of preventing guns from occupying exposed positions, should the attempt be made. To extricate guns thus exposed, once the enemy has been enabled to bring accurate fire to bear on them, is likely to prove a matter of much greater difficulty. In other words, mobility is liable to be sacrificed. For similar reasons the replenishment of ammunition may be rendered very difficult.

Exposed guns forming as they do a comparatively easy target for hostile artillery fire, may find themselves engaged in an unequal contest, unable to carry out their task, and unable to move in order to re-commence it again under more favourable circumstances.

On the other hand, the occupation of covered positions tends to complicate that rapid control and direction of fire which may be essential to the support of infantry.

It is constantly a question, therefore, of how far we can afford to obtain immunity from the above-mentioned disadvantages at the expense of the efficacy of our own ammunition. The war experiences and teachings of Russians and Japanese on this subject are, I believe, supposed to be somewhat antagonistic.

I think that the differences are more apparent than real. Although the Japanese favour direct fire positions, they are careful, in practice, to lay great stress on concealment in action. As our shields afford us reasonable cover, the ideal position would appear to be a direct fire position, easy of access and one in which the advantages of concealment are obtained by utilizing existing topographical conditions or artificial means.

Such positions are not easy to find on our practice grounds, and even if they were, the element of time would often debar their use. Their value in war, however, especially when fighting in enclosed country, should not be lost sight of. 
As I have already intimated, I think that it is concealment and not cover which we have principally to aim at, though under certain circumstances, it comes to very much the same thing.

\section{CONCLUSION.}

I have attempted to outline certain guiding principles to further co-operation between artillery and infantry.

So far as my limited knowledge goes there is no one of these principles in which, if we have not yet arrived at perfection, we are not, at any rate, doing our best to attain it.

\section{DIScussion.}

Major-General J. L. Keir, C.B.: Sir James Grierson, ladies and gentlemen: What we are discussing this afternoon has been described as the most complex problem of contemporary tactics. I think the complexity mainly consists in the endless varieties of ground and in the manifold dispositions which are made by an enemy. If this subject be discussed generally, not very much progress will be made; I think the best way of dealing with it is to break it up into a number of smaller questions and take them in turn.

There is no doubt that it is much easier for the artillery to support a small body than a large one; that is to say, if you have two batteries and an infantry brigade it is very much easier for them to give close support than it is when you have a large body of artillery supporting an infantry division. For this reason, that when the two combatants are coming close together there is more danger of your own side being hit. It is quite easy to fire over men's heads when you are a long way off, but the closer your men get to the enemy the more danger there is of their being hit. This question of the artillery support is not being treated sufficiently as a branch of military art. I do not think we have given a fair chance to this effective support of the infantry. After all, it is only an enlargement of the firing support which is given by the infantry-covering fire-and on which so much stress is laid; with this difference, that instead of the bullet you have the shell. The modern shell, of course, is improved very much, but the only question is whether we are not treating it with too much deference at the present time. I should like to see a little more manceuvring in front of loaded guns than is carried out at the present time. I think more progress would be made.

If we come to practise this, might I suggest one or two things? One thing is that at present I do not think, when we are going to carry out an attack, that it is clear whether the officer commanding the infantry is in absolute charge, or whether the guns are merely going to support him. Until the officer actually commanding has complete authority to give orders to his guns 1 do not think we shall have effective support. It is done in the case of a rearguard. You do not question that the officer commanding a rearguard has the charge of his force absolutely at his disposal, and I think that should be done in the case of small groups.

Then again, I think it is useless to hope for any progress unless live ammunition is fired. Realism is wanted as much as possible. I also think the ground ought to be varied. It is no use practising over 
the same ground. You should have a different lesson to teach each time. You must vary your ground in teaching. With regard to battles of the present day, of course the officer in supreme command places the troops in position, but it is quite evident that the fighting is done by the subordinate commanders. 'The general, so to speak, holds the sword in his hand, but the sharpness of it depends entirely on the training of the subordinate leaders. In this matter the close support of infantry by guns is an extra weapon placed in their hands. We are now dealing very successfully with infantry firc support, and I think we might go a little further and deal a little more practically with artillery fire support. We are all very much obliged to Major Budworth for his lecture, which leads us to suggest further practical remedies which I hope will be carried out.

Lieut.=Colonel J. G. Geddes, R.F.A.: I have studied this question closely for many years from different points of view. (I) As a battery and artillery brigade commander; (2) as an officer of the School of Gunnery; (3) as an umpire at various periods with the Ist, 2nd, $3^{\text {rd, and }} 4^{\text {th }}$ Divisions; (4) as an officer of a divisional staff. From my experience I am convinced that true co-operation between artillery and infantry depends on the personal equation of the officers of each arm. Unless a thorough entente cordiale exists between artillery and infantry officers (more especially the field officers), co-operation is seldom successful. To obtain this entente cordiale, or understanding, artillery and infantry must be quartered together at the same station.

\section{Intmate Association of lnfantry and Artillery Officers.}

With regard to training, the officers, by hunting, shooting and playing games together acquire mutual friendship, which quickly extends to N.c.o.'s and men, and that is the first and perhaps the most important step in training. The second step is the association of officers of all ranks at regimental exercises and brigade tours and conferences. Thirdly, during certain periods of battalion training, scetions and batteries of artillery should take part; the battery commander assisting the battalion commander in the preparation of the schemes. Finally, at infantry brigade training, the artillery should take part as desired by the infantry brigadier.

Artillery officers not with the guns should be utilized as umpires, and artillery field officers should take their turn with infantry field officers in command of mixed forces. At artillery practice camps the infantry officers should attend with the artillery brigade with which they associate. Training on the above system should be carried out prior to divisional training, and can be performed without interfering in any way with the technical artillery training of batteries and brigades. At all combined operations in which artillery and infantry take part, the Director should make it a point to deal with the action of the artillery as well as that of the infantry in his remarks. This is sometimes forgotten, and I may say that nothing kills the zeal of artillery more effectually than being ignored in the remarks made at conferences. When divisional training takes place it will be found that the close association and understanding which has been fostered between artillery and infantry, in the earlier stages of training, enables the divisional commander to devote the whole time at his disposal to the instruction of the division as a fighting unit.

With regard to action, the recent edition of Field Artillery Training lays down certain broad principles for the co-operation of artillery and 
infantry. These principles are clear, and if carried out, are sufficientbut here again we find the personal equation of the officers concerned is all important, An artillery brigade commander, intimately and personally acquainted with an infantry brigadier and his staff, has seldom any difficulty in ascertaining the tactical situation as regards the requirements of the infantry he is ordered to support. He can do this at critical moments without intrusion where a stranger might easily fail. If he is not actually present at the infantry brigade headquarters, the officer left to represent him (probably a young officer) finds his task much easier owing to his personal acquaintance with the staff. Therefore, I am strongly of opinion that the personal equation of officers is of the greatest importance in co-operation between artillery and infantry.

\section{Distinguishing Friend from Foe.}

Turning to the difficulty of distinguishing friend from foe, I think that can be minimized either by sending forward an artillery officer into some position in which he can see exactly where our own infantry have got to, or else by pushing the guns forward and not keeping them too far behind. Here, again, the intimate acquaintance between artillery officers and the infantry units is of very great value. Certain regiments one has no difficulty in recognizing; for instance, the Gordon IIighlanders. Perhaps a scheme might be devised whereby some sort of badge could be carried by our infantry on their backs, which would be out of sight of the enemy. With regard to sending back information to the guns from the firing line, the information for the guns should come from the firing line to brigade headquarters, and then be transmitted to the guns. On certain occasions it may come back direct to the guns. On the last day of the army manœuvres this year, a counterstrolse was about to be delivered. A battalion commander called up my guns direct and said, "My battalion and the battalion alongside are about to deliver a counterstroke." We received that information and were able to support that counterstroke. But there is a danger in allowing infantry units to communicate back to the guns from the firing line, namely, that the guns may be diverted from the main objective to take part in some local and unimportant affair.

Rrigadier.General F. J. Davies, C.B.: I had no intention of taking part in this discussion, but as the Chairman has called upon me I may say that I agree with what the last speaker has just said about the danger of information coming to the guns direct from the firing line. In the particular instance which Lieut.-Colonel Geddes mentioned, the gunner used his own discretion, but he might not have done so. There is a very great danger that the gunners will get an urgent message to concentrate their fire on some unimportant area. When we are under heavy fire we always imagine that the particular part of the battle which we are fighting is the one on which the fate of the Empire depends. That is why I think it is certainly better that information to the guns as to what particular part of the attack they are to support should come from the responsible superior commander and not from some doubtless very gallant but subordinate commander in the infantry firing line.

Major H. Rowan-Robinson, R.A., said that co-operation had been discussed for the last 50 years, but he was not sure that they were any nearer the practical application of it. The real difficulty was to find some simple system of applying it. There was no doubt about the 
importance of supporting the infantry up to the last moment of the attack; but, at present, according to Field Artillery Training, the guns must cease firing, depriving the infantry of their artillery support at the moment when they were going to deliver an assault. At present, out of 72 guns in a division, the assault could be supported by only 18 howitzers. The only way, so far as he could see, to utilize the remaining guns would be to introduce a separable charge. This would involve double range tables, but he did not think there was necessarily any difficulty about their use. It was only necessary to have two differently marked range drums to each gun. The separable charge itself would only entail some structural alteration in the limbers and wagons.

It was, in his opinion, of no great importance to turn the fire on to the reserves. It was the fire from the enemy's trenches which stopped the attackers' firing line, and the reserves were not very likely to choose the moment of assault to reinforce their firing line. They were far more likely to hold themselves ready in rear to deliver a counter-attack as soon as the assault had been delivered. Therefore the important thing was to shell the enemy's trenches and not his reserves.

\section{Attachment to Other Arms.}

It was certainly an admirable thing to establish an entente cordiale between the two arms, but that hardly went far enough. Artillery could not properly support infantry unless each artillery officer knew a good deal more than the average artillery officer did know about the practical handling of infantry. Officers were often attached to other arms, but, to his mind, it was perfectly useless to attach an officer to any other arm unless he was given the responsibility of leading the troops of that arm. Infantry officers might watch artillery practice and artillery officers might watch infantry carrying out an attack, but unless the infantry officer had charge of the guns or the artillery officer had charge of a company or even of a section, he would never learn what were the real difficulties of handling the troops, learn how to deal with the ground, and so on. It was, perhaps, impossible to attach every infantry officer to a battery and give him a command, but it was quite possible to attach most field artillery officers to infantry. It was more important that the artillery officer should learn the procedure in action and the methods of leading of infantry than vice versa, because it was the artillery who had to support the infantry and not the infantry who had to support the artillery. The artilleryman was to a great extent the servant of the infantryman, and it was his business to learn the job of the infantryman.

Brigadier-General N. D. Findlay, C.B.: I should like to draw attention to the necessity of timing the advance of a body of infantry to the attack so that it shall not commence until the artillery detailed to cover its movement are ready to open fire. It is not always realized how long batteries take to come into action after the general plan of attack has been decided upon. They may have to advance a considerable distance over brolien ground, and in any case the reconnoitring and selection of positions from which they can carry out their missions requires time. I think it should be clearly understood that, in order to avoid the risk of any failure in the co-operation of the guns, and the possibility of the infantry finding itself under hostile fire unassisted by its own artillery, the advance should not be ordered, until the artillery commander reports that he is ready to support it. 


\section{Position of the Infantky Conmander.}

The next point to which $I$ would refer is the actual position selected for himself by an officer commanding a force of infantry which is supported by artillery. In order to get the fullest possible benefit from the artillery it is desirable that he should have the artillery commander with him. But the latter officer must be where he can see what is going on, and I therefore submit that the commander of the infantry should select his own position with due regard to the requirements of the artillery as well as to those of his own arm. I know that an infantry brigadier often likes to be with his reserve, or at some place where he can get his messages from his divisional headquarters or from the front, but the maintaining of close personal communication with the officer commanding the supporting artillery is so important, that it is worth trying to find a place which will suit them both. I would also urge that the infantry commander should change his position as seldom as possible. Every move means for an artillery brigade commander dislocation of communications, and a critical period in the fight may occur just when a move is taking place.

There is one difficulty we have to contend with in connection with the support of infantry at the commencement of an offensive action, namely, that the enemy will almost certainly have his guns completely hidden behind cover. He will open fire upon our infantry and probably we shall not be able to locate his guns. At present we have no means of locating them, and we are told in the Training Manual not to expend vast quantities of ammunition upon an objective which we do not see. What is very much wanted, therefore, is more practice in locating targets in concealed positions, and bringing fire to bear on them by means of observation from aircraft.

Such observation, I suggest, ought to be regularly carried out at all our practice camps. Last year some experiments of this nature took place, aeroplanes being employed, but it seemed to me everything was so slow with the aeroplane. It had to circle over a battery, then go round and come back again. I think what is wanted is practice with captive balloons, and, when the weather is unfavourable for them, with kites. To a certain extent observation of artillery fire from a captive balloon was carried out during the war in South Africa, but I have not heard of this being tried of late years, and I am convinced that it is necessary.

The next matter I should like to deal with is the question of some means being provided of indicating to the artillery how far our own infantry have advanced in an attack. Some years after the war we did a lot of practice with flags and screens, but that has been dropped. It is absolutely impossible to tell friend from foe, and 1 am sure we ought to start practising again at manœuvres, with some sort of appliances of the nature of flags, screens, or Dietz discs. Certainly during some periods of this year's mancuvres it was impossible to tell whether the various lines of infantry which appeared on the battlefield were our own friends or belonged to the enemy.

Brigadier=General E. J. Phipps=Hornby, V.C.: I am rather sorry that more infantry officers have not taken part in this discussion. I am afraid most of us here are artillery officers, and I think we are all agreed as to the importance of co-operation. Before I came to this meeting I 
looked up in a dictionary the meaning of the word "co-operate," and the definition I found given was, "to labour together for the same end." All artillery officers that I am acquainted with are always labouring to assist infantry; but when $I$ have spoken to infantry officers on the subject I have always met with difficulties:-" They cannot spare the officers; they cannot let us have the telephone lines," and so on ; it is a pity they do not "co-operate," that is to say, the infantry and artillery officers do not work together for a common end. I think, if our handbooks on drill are looked at, it will be found laid down that it is the artillery who have to co-operate with infantry; but I maintain that the proper rule is that the two arms should co-operate together, and $I$ think that is the direction in which we want to move. How it can be done is a difficult question. I have heard it discussed very often, but I have never heard any very clear solution expounded.

\section{Objections to Artilleky Officers in the Firing Line.}

A few years ago the point of the necessity of having an artillery officer in the firing line was very much emphasized. I am sure nothing could be more fatal to a successful issue to an action than to have artillery officers in the firing line. Artillery officers can be spared for the firing line in times of peace, because no bullets are flying, and there are as many of them at the end of the day as there were at the beginning; but in the case of real warfare there would be a good many missing. What is more important is that $I$ do not believe the information which they would send back would be worth anything. As infantry officers know, when anybody is in the firing line all they see is a very small area in front of them, and their whole interest is concentrated on that area and their feeling is that the fire they are suffering from is more severe than what anybody else can be suffering from, and naturally they send back and say, "Here is where the fire of your guns is wanted." I am quite sure we do not want any artillery officers in the firing line. Where they ought to be is with the brigadier-generals of infantry. They could then give information to the brigadier-generals, who could either act on it-if it seemed to be sufficiently important-or it could be referred to the artillery commander of the whole division for his opinion.

\section{Difficulties of Communication.}

Then comes in the question of communications, which is a most difficult one to contend with at the present time. There are not sufficient means of communication. Telephone lines are installed between the brigadier-generals of infantry and their battalions, and the divisional general is linked up by other lines, but these lines are not sufficient for the work they have to do. I know from my own experience of commanding the artillery at five or six divisional trainings and mancuvres that if you want to get your messages through the Signal Company's lines you have to wait a very long time. On one occasion of this year's manouvres I sent a message to one or two brigades of artillery. The number of words was over 85 , and it, of course, took an exceedingly long time for the Signal Company to write down 85 words in the stereotyped way in which it is done, to have them sent through to the other end and copied off again and for a messenger to take the message to the unit concerned. I think some other arrangement ought to be made with regard to means of communication. I believe the simplest way would be to employ men 
on horses or men on bicycles. Of course, it depends what the country is like.

\section{Need of Distinguishing Marks on Flags.}

Flags are useful, but they are no good unless there is some distinguishing mark on them. I speak with some feeling on that point, because at some manceuvres about six years ago I was with the cavalry, and I left three batteries of horse artillery on a hill behind me and told them I would signal to them when I wanted them to come on. I signalled for the best part of an hour without getting them to see me, and at last one of my subalterns came galloping up and said, "All your batteries are "scuppered." I said, "What has happened?" He said, "A squadron came through and has talien the lot; they are all out of action for 20 minutes." I said, "I have been calling you up for the last hour. Why did not you see me?" He replied, "If you were back there you would see hundreds of flags all signalling at the hill, and we could not distinguish our flag." The result was that the batteries were "scuppered." I have advocated the idea of coloured flags for artillery for a good many years, but I am sorry to say without any result.

With regard to my suggestion of men on horses and bicycles, I would point out that the distance they would have to travel would never be very great. I believe at this year's mancuvres no horsemen or cycles would have had to go more than two miles to get to the furthest brigade. I am quite sure that this means of communication would be a good deal quicker than writing all these messages and sending them through the telephone lines.

Of course, there is only one position for the C.R.A., and that is with the G.O.C. of the Division; there is no doubt about that, and 1 think it is beating a dead horse to talk about it. With regard to the control by superior and subordinate commanders, I think that matter is well understood at the present time. With regard to the difficulties of distinguishing between friend and foe, that is a matter about which something ought to be done. It certainly is very difficult to distinguish friend and foe, and $I$ should be very sorry to say how often during the war I shelled some of my own side.

One point in the paper was of the greatest interest to me, but it is a point on which I do not agree with Major Budworth. He referred to shields being of a certain amount of use. I do not believe they are as valuable as he imagines. I have made diagrams of them with a shell fire coming from 1,500 yards, and you may take any shell you like which bursts in line with the shield and just in front of it, and you will find that the whole detachment will be knocked out by the bullets of that shell. If that can be done at 1,500 yards it must be done much more easily when you get a longer range. The shield ought to be much higher, in my opinion, and $I$ do not know why it is not, except that it is a matter of weight and a little difference in the centre of gravity.

There is another matter which I think ought to be enforced. There have been doubts about it for some time, but I am glad to see that opinion seems to be coming round more to the one standard; that is with regard to the issuing of Divisional Orders. The artillery is not a local arm at all. Artillery has to support infantry in every part of the field, and so I think it is incumbent on every artillery officer to know exactly what is being done by the division and what the General of the Division intends to do; and I think those Divisional Orders ought 
to be sent in full to every brigade of artillery. When first I went in the $4^{\text {th }}$ Division nearly four years ago, there was a great inclination not to send out the Divisional Orders to anybody except the C.R.A., but I am glad to say that now-a-days the authorities seem to be coming round to the view, which I think was originated by General Davies, that every brigade of artillery should have the Divisional Orders.

The Lecturer, Major C. E. D. Budworth, R.H.A., in reply, said: I do not think that there is much need for further discourse on my part. Those officers who have kindly made criticisms have stated their points of view very clearly. I shall confine myself to offering a slight personal explanation. I did not do so when I started my lecture, because I was taught to avoid it by an American citizen, who once remarked to me that most Englishmen when they got up to make a speech started by apologizing for not being able to do so and then went on to prove it. That has always made me careful not to commence with an apology. But the apology I now want to make is for speaking on this subject before so many officers who I realize have very much greater experience than I have. I can only thank you, Sir, for presiding, and you, gentlemen, for the very kind attention which I have received.

The Chairman, Lieut.: General Sir J. M. Grierson, K.C.B.: Gentlemen, I do not think that Major Budworth needed to make those last remarks of his. $\mathrm{He}$ is well known amongst us as an authority on artillery matters, and as a matter of fact I believe he has had a good deal to do with the writing of Field Artillery Training, the principles of which he has been so ably expounding to us to-day. His lecture, to my mind, is simply an enlargement of the regulations which are laid down in our Field Artillery Training, and in Field Service Regulations, which, of course, enunciate the same principles.

There is no doubt that co-operation between the two arms must start from the top, and the control of both the artillery and the infantry must be in the hands of one man. It does not matter what the size of the force is. The divisional commander, as long as his division is working to one end, must keep control of the whole of the artillery in the hands of his C.R.A. If any portion of the division is detached, or is working for a particular object, and is more or less separated, then a smaller group for fighting is formed, and a portion of the artillery is placed at the disposal of the officer commanding that group. If a brigade of infantry is told off for a certain operation, then artillery is, by order, attached to it, and it is laid down in Field Artillery Training that the officer commanding that artillery has to report himself at once and place himself at the disposal of the officer commanding the infantry. This same principle applies to units below a brigade. The one great principle which must be maintained, if success is going to be attained, is to keep the control of as much of the artillery as possible in the hands of the commander of the body of troops, whatever it is.

What General Findlay said about the position the infantry commander should take up is very important. He must also think of the co-operation of the artillery, and it is very desirable that he should be in immediate touch with its commander. Therefore, in choosing his position he should try to get a place which would suit the artillery officer's requirements as well as his own. It will generally be found that a place which suits the artilleryman will also suit the infantryman. If the artillery com- 
mander has to go away some distance from the infantry commander, he must leave somebody with him. I quite agree with General PhippsHornby that it is sheer nonsense to have artillery officers in the firing line. That can never be. Their view must be limited there, they only get a small local impression of what is going on, and they would never get their reports back in time to be of any use. The furthest forward he should go is to the station of the commander of a brigade, or perhaps even of a battalion, but no further.

\section{Practising Co-operation in Peace.}

WVith regard to the question of how we are to train in time of peace for that co-operation which is so essential in war, I most thoroughly agree with Colonel Geddes and Major Rowan-Robinson that the way to ensure co-operation in war is to make the officers of artillery and infantry as intimate as possible in time of peace, and the first thing is to teach them what the others do. Artillery officers must be attached to the infantry as much, as possible. I linow it is very difficult to get officers enough to do the work, but it is so important that artillery officers should know the methods of infantry that I think everything possible should be done to attach artillery officers to the infantry. They need not be permanently attached, but a brigade of artillery could be affiliated to a brigade of infantry for training purposes, and the officers can go out with its units when any field work is being done. Of course, it is very important that the officers should do practical work; they will never learn anything by simply looking on. W'hen I was in command of a division at Aldershot, by my orders the artillery majors and captains took command of companies of infantry, and they performed that duty exceedingly well. That is the way for artillery officers to learn the principles of infantry work and get that personal equation which Colonel Geddes referred to.

The attaching of infantry officers to artillery is a more difficult matter, and as someone said, it is not so necessary. But it is very necessary that they should attend artillery practice camps in order to see what the artillery really can do. Above all, it is necessary at all periods of training-I will not say company training, but certainly battalion training and upwards-that artillery should as much as possible go out with the infantry and the two arms work together.

It only remains for me to thank Major Budworth in your name for his interesting lecture, and I also think we ought to congratulate ourselves on having heard a very great deal of sound opinion from the officers who tooli part in the discussion.

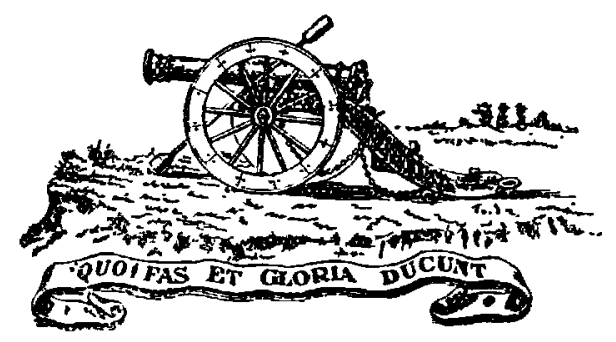

